\title{
Marketing Practices of Hotel Chains
}

\begin{abstract}
Hotel companies' marketing-planning procedures have achieved considerable sophistication in the last ten years. But many plans have become overly complex. And in the rush to establish financial objectives, many companies' plans seem to have lost sight of guest satisfaction
\end{abstract}

\section{by Chekitan S. Dev}

AS RECENTLY as ten years ago, American hotel operators were developing only rudimentary marketing programs - most of them really merchandising and sales techniques. Today, as this article will show, most hotel chains have recognized the importance of the marketing function and its critical role in the success of their operations. As Howard Feiertag put it: "A hotelier who does not consider marketing as a major part of the hotel's operation is doomed to failure."1

There has been little direct research on how hotel companies develop their marketing plans. One research study did examine manufacturing and service companies, while another discussed package-goods purveyors. ${ }^{2}$ To fill

${ }^{1}$ Howard Feiertag, "Small Properties Have a Special Need for a Marketing Plan," Hotel \& Motel Management, October 13, 1986, p. 25.

${ }^{2}$ See: David S. Hopkins, The Marketing Plan (New York: The Conference Board, 1981); and Stanley F. Stasch and Patricia Lanktree, "Can Your Marketing Planning Procedures Be Improved?," Journal of Marketing, 44, No. 3, pp. $79-90$. the gap in hotel-related information, I conducted a comparative study of planning practices in 12 hotel companies, all based in North

Chekitan S. Dev, Ph.D., is an assistant professor of marketing at the Cornell University School of Hotel Administration. He was assisted in preparing this article by Alice Segovia, who holds a Master of Professional Studies degree from the Cornell Hotel School. Funding for this study was provided by a grant from the School. 


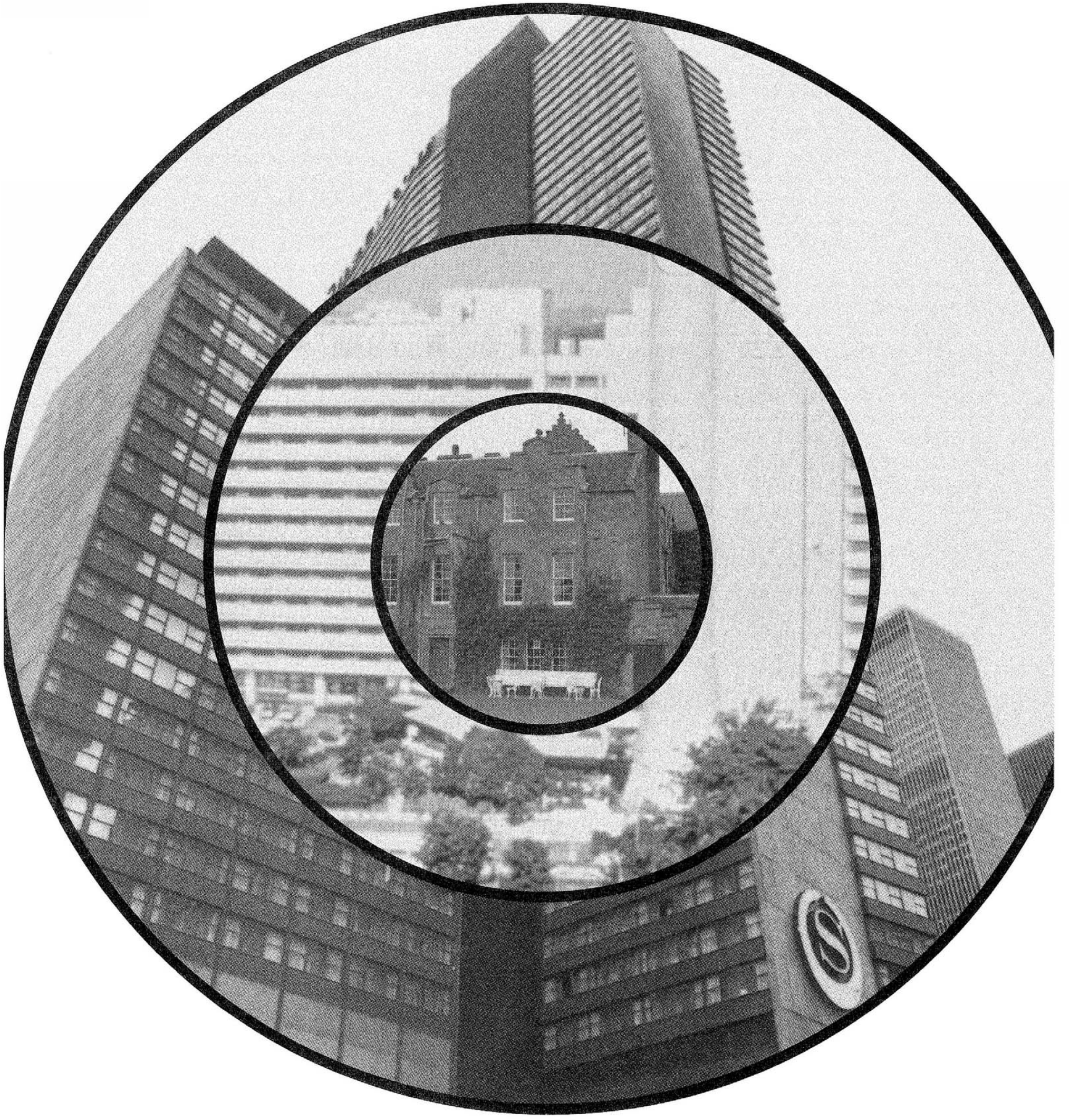


America (see Exhibit 1). My purposes were (1) to identify and describe the marketing-planning procedures used in various hotel companies; (2) to compare and contrast those procedures; (3) to establish benchmarks or guidelines, if possible, that appear to be associated with good marketingplanning practices; and (4) to try to determine the effectiveness of each company's marketing-planning practices by its financial performance.

I conducted my research during the summer of 1989. To begin, I wrote to the 25 largest hotel companies in North America to request their participation. Twelve companies indicated their willingness to participate. The participating companies represent all segments of the hotel industry. Two chains operate luxury hotels, four have first-class properties, three are primarily in the midscale market, and three are economy operators.

I used the questionnaire shown in Exhibit 2 as the framework for a series of 43 interviews with key marketing executives at the corporate and property levels. Before going into the interviews, I familiarized myself with the companies by reviewing their financial statements and reading articles published about the companies in trade and academic journals.

To ensure that the information I gained in these interviews was as unvarnished as possible, I pledged that specific information would remain confidential. Consequently, this article discusses the hotel companies without providing the kinds of descriptive information that might make them identifiable.

Dimensions. In the course of my interviews, I asked the marketing experts to characterize their marketing-planning procedures along the following six dimensions: ambitious versus conservative objectives, simple versus complex documentation, short-term versus long-term goals, top-down versus the bottom-up approach to setting objectives, rational (fixed) versus incremental (reviewed and adjusted) development, and sequential (step-by-step in one direction) versus iterative (loop-back) planning process.

Effectiveness. I also tried to judge whether each company's marketing planning was effective. I considered the process effective if forecasted revenue projections in the marketing plan showed less than a five-percent variance from actual results. Unfortunately, I was frustrated in this effort. To begin with, I could acquire little hard data. Most of the information presented came from the personal recollections of the persons I interviewed rather than documented figures. Moreover, the company with the most thorough planning process reported results with a variance greater than five percent from the budget (happily, a positive variance). Moreover, two companies with less-thorough planning processes reported a variance of less than one percent.

I have concluded that a single year's results cannot demonstrate the effectiveness of the planning process and one would need many years of financial information to do so. It may be that even a lengthy series of results will have no correlation, owing to such uncontrollable factors as economic recessions, heavy debt from an acquisition, or acts of nature that would affect a company's performance. For the purposes of this article, I propose that a measure of marketing plans' effectiveness based on scoring high on criteria specified in the literature works well. ${ }^{3}$

${ }^{3}$ Stasch and Lanktree, op. cit.
Benchmarks. To compare the planning practices of the 12 hotel companies, therefore, I selected four characteristics to evaluate how thorough each company's planning process was. I ranked the planning process high if it met the following four tests:

(1) The company used input from different levels of management;

(2) The company used external and internal sources of information (e.g., an outside advertising agency and in-house marketresearch department);

(3) The length of time scheduled for the marketing plan's development was appropriate to the task (i.e., two or three months of development would be more appropriate than two or three weeks); and

(4) A number of organizational and motivational factors were used to encourage good planning over time, including training programs and bonus or incentive plans based on sales or profits resulting from the marketing plan.

\section{Company Descriptions}

The hotel companies I surveyed were by no means uniform in their approach to marketing planning. Two were standouts for the thoroughness of their planning processes. Five others ranked slightly below the top two primarily because they presented little evidence of having a training program for marketing planning and provided only guidelines for developing the marketing-plan document. The other five ranked even lower in their marketingplanning procedures because they either offered no training or had no incentive plan, and they failed to include property-level management or outside sources in the planning process.

Diversified. Hotel Company A, one of the two with the most 


\begin{tabular}{|llll|}
\hline EXHBIT I & & & \\
Participating firms & & \\
Best Western & Holiday Inns & Motel 6 & Ritz-Carlton \\
Days Inns & Marriott & Omni & Sheraton \\
Four Seasons & MHM & Ramada & Westin \\
\hline
\end{tabular}

\section{EXHIBIT 2}

Marketing-planning questionnaire

\section{Organizational philosophy}

Mission statement: What does the company stand for?

Nature of the company's business?

Who is the customer?

Who is the competitor?

\section{Marketing philosophy}

Role of marketing in the organization

Guest satisfaction versus operational efficiency

System to monitor, trace, or address guest satisfaction-results? Is it working?

\section{Selloassessment}

Strengths: What is your key competitive weapon? Do you use it?

Weaknesses: What is your Achilles' heel?

Opportunities: Where will you grow?

Threats or limitations: Barriers to growth?

\section{Marketing direction}

Objective: Where do you want to be in five years?

Strategy: How do you aim to get there? Expansion or acquisition?

\section{Key result areas}

What is your focus for the 1990s?

\section{Marketing organization}

Lines of authority (real versus imagined)

Span of control, specialization

\section{Marketing planning}

a. Forms? Documents? Time frame?

b. Sources of input:

Senior management: Direction? Involvement?

Staff and line management: Number? Areas? Levels?

c. Steps

Research: Scanning? Competitor analysis? Product? Customer?

Planning: Objective setting: Very ambitious, optimistic, realistic, pessimistic, or very conservative. Scenarios? By segment?

Strategy: Conflict with corporate strategy? Action plans?

Execution: Freedom? Discretion? Course Correction? External sources?

d. Characteristics

Simple versus complex,

Short-term (three months) versus long-term (five years)

Top-down versus bottom-up

Rational (fixed) versus incremental (reviewed and adjusted)

Sequential (one shot at each level) versus iterative (drafts are reviewed and revised)

e. Facilitation

Training or development

Incentive plans or other motivational factors

f. Assessment and measurement (last $1-5$ years)

Percentage market-share trends

Sales trends

Growth trends

Variances-Actual versus budget: Typical? Most recent?

g. Future

Important issues? intricate marketing-planning processes, is part of a large, diversified, multi-national corporation. The firm comprises companyowned and company-managed hotels, along with a substantial number of franchised properties. Most of the properties are midmarket. Company A's planning process begins with a five-year strategic plan that is examined and reviewed every three years. In the strategic plan, the company states what it will be, what it will do, and where it anticipates being at the end of five years. From the strategic plan, the company's hotelbrand managers develop their annual marketing plan.

In developing the marketing plan, the managers of each product meet and review the objectives of the strategic plan. These objectives are translated into objectives for each individual department. Annual marketing plans are reviewed at the top level for approval. Because the company is publicly traded, it maintains both an external and an internal plan. The goals written for public consumption are somewhat less aggressive than those held internally for actual operation. Franchisees are not required to prepare an annual marketing plan.

The company's marketing-plan document is written in a structured, standard format. Many forms and tables are used for consistency in presenting the information.

Upscale. Company B, a wholly owned subsidiary of a multinational conglomerate, is a large, international firm that has mostly company-managed and franchised hotels, with a few company-owned hotels. All are of at least first-class or business rank. Company B's planning phase begins in April and ends in July. By mid-eJuly, marketing plans are due at the regional office for review by management at 


In their effort to make
marketing plans simple to
develop, most hotel
companies have made the
process more complex.

that level. In August, regional and property executive committees conduct budget-review meetings. After the marketing plan is reviewed in detail, it is ready for approval at the corporate level in September. In October, all marketing plans are incorporated in the corporation's annual marketing plan.

The hotels are given clear directions and procedures for the planning process that results in the written marketing-plan document. Corporate management sets revenue requirements and objectives for each hotel. Many standard forms are used to ensure consistent input that has been generated through a specific process in each hotel.

Luxury. Hotel Company C owns and manages a small group of luxury hotels in several countries. Its marketing-planning process begins informally at the company's annual marketing conference, where a number of important issues are raised. Senior-level managers then discuss the issues that are relevant to the entire marketing organization and all hotels for four to five days. After this interaction, the most important issues are listed and combined with extensive research and analysis to set the basis for the annual marketing plan. The data received from these analyses are also discussed in open forums within the company.

The formal marketing-planning process is divided into two levels, corporate and property. Corporate planners set the budget outlines for the planning process at the local properties. These outlines and guidelines are established before the individual properties begin developing their annual marketing plans. The properties then develop their own objectives and work the company's guidelines into their marketing plan.

Once marketing plans are developed, they are distributed to all corporate managers for a detailed review. Corporate managers meet to approve the hotels' plans for occupancy rate, revenues, expenses, strategies, budgets, and promotions. Managers of the individual hotels are advised of the results of these deliberations and given two to three weeks to make revisions. With the local hotels' plans in place, the planning and review process begins for the total corporate budget. A team of corporate managers goes to each hotel and reviews the budgeted revenues and expenses line-by-line with the property's general manager, controller, food and beverage director, and marketing director. After their marketing plan is approved, the hotels complete their operating budgets.

In preparing their marketingplan document, hotels are given a structured format as a guideline and, in turn, they must submit drafts of the marketing plan according to the timetable outlined above.

Management. Hotel Company $\mathrm{D}$ is a small management firm (under 100 properties) that operates a variety of hotel products, most of them franchises of major national brands. The company's marketingplanning process begins with defining or redefining its mission statement. Next, top management conducts an extensive process that includes an area-demand analysis, competitive analysis, property evaluation, and development of the customer profile. This step is followed by an area forecast, competitive-rate analysis, formulation of a positioning statement, ${ }^{4}$ development of strategies and objectives, and estimates of projected penetration, market mix,

${ }^{4}$ For a discussion of positioning statements see: Robert C. Lewis, "Advertising Your Hotel's Position," The Cornell Hotel and Restaurant Administration Quarterly, 31, No. 2 (August 1990), pp. 84-91. 
rates, and revenues. Finally, the firm develops an action plan.

The company provides its managers with a detailed marketing manual that describes the contents of the marketing-plan document. This document is structured, and many forms are used in the planning process. The basic impetus for the marketing plan's development, however, is at the property level, where objectives and strategies are formulated and incorporated into the company's corporate marketing plan.

No formal plan. Company $\mathbb{E}$ is a large, national chain that owns and operates all its properties, which are primarily highway motels. This company does not follow a formal planning process. In my interview, I could discern no evidence of a specific, written marketing plan. Instead, company objectives are reviewed every trimester. That review is considered to be the company's plan.

Detail. Company $\mathrm{F}$ is a small, international hotel chain with deluxe first-class company-owned, company-operated, and franchised facilities. This firm's planning process begins with its overall mission, from which objectives are established. Management develops corporate strategies to achieve these stated objectives. Every corporate manager in the various function areas carries these objectives and strategies down to the property level.

Each hotel property is given a detailed outline of the marketing plan's contents. The document consists of eight major sections in a standard format with many tables and forms to complete. Managers go through a detailed planning process that includes a supply-anddemand analysis, an evaluation of the property, an economic profile, and a review of the property's positioning statement. Department heads then develop strategies and action plans that include specific action dates.

All of these analyses are documented in the marketing plan, including elements of room merchandising, food and beverage merchandising, capital expenditures, and revenue projections. The marketing plan is reviewed jointly by a corporate team and the property's management team. After the plan is approved, the hotel property makes its budget final, and the corporate marketing plan is developed using the input from the individual properties.

Pre-opening. Hotel Company $G$ is a small, luxury hotel chain that owns and operates properties in the United States. Its marketing-planning process begins during the pre-opening phase of a hotel property. The firm conducts background research on the locale and its competitive environment. The information garnered from this study is reviewed in a two-day meeting involving corporate headquarters, regional management, the hotel's marketing staff, and the hotel's advertising agency. Out of this meeting comes a preliminary market assessment that identifies the market segments important to that property, the characteristics of those segments, and the competition. The plan also establishes priorities for the marketing resources that should be used to secure the targeted market segments. In a final meeting, hotel managers agree on the assessment, establish sales objectives, develop advertising and public-relations strategies, and formulate a budget. They prepare a written plan that is implemented after the budget is approved by corporate executives.

Once the property is open, Company $\mathrm{G}$ hotels follow an annual marketing-planning process that includes a detailed review of the previous year's results, guest histories, competitive analysis, identification of potential opportunities, development of strategies, and the preparation of a written plan and budget. While guest satisfaction is the cornerstone of the company's stated mission, hotel general managers' bonuses were based primarily on hitting targets for gross operating profits.

Brainstorming. Company $\mathrm{H}$, a large referral organization, provides affiliates with brand identification, a central reservation system, and basic company standards. The corporate marketingplanning process begins with brainstorming sessions on key market segments. From these sessions, market-share expectations are established and objectives are developed. Management conducts a competitive analysis on rate and physical plant. Then the company sets strategies, tactics, and action steps in a written planning document.

Providing direction. Company I is a large, economy chain with franchised properties chiefly in the United States, although it is expanding in other countries. In its planning process, senior management provides direction in developing objectives and strategies for the company. With this direction, individual departments prepare their own plan with specific tactics and action steps. These plans are consolidated into a single, annual corporate marketing plan.

Centralized. Company $\mathrm{J}$ is a large, diversified, multi-national corporation that owns, operates, and franchises hotels in several market segments. The marketingplanning process is centralized in this chain. Property managers deal only with the execution of the marketing plan and are not involved in the planning process, which takes place at the division and regional levels. 


\section{EXHIBIT 3}

Comparison of marketing planning characieristics

\begin{tabular}{|c|c|c|c|}
\hline & $\begin{array}{l}\text { Senior-level management } \\
\text { (Corporate and regional) }\end{array}$ & $\begin{array}{c}\text { Property-level } \\
\text { management (GM and } \\
\text { executive staff) }\end{array}$ & $\begin{array}{l}\text { Outside agencies } \\
\text { (Research, PR, etc.) }\end{array}$ \\
\hline Company A & Yes, much & Yes, much & Yes, much \\
\hline Company $B$ & Yes, much & Yes, much & Yes, much \\
\hline Company C & Yes, much & Yes, much & Yes, much \\
\hline Company D & Yes & Yes & Yes \\
\hline Company E & Yes, much & None & Yes, much \\
\hline Company $F$ & Yes, much & Yes & Yes, much \\
\hline Company $\mathrm{G}$ & Yes, much & Yes, much & Yes \\
\hline Company $\mathrm{H}$ & Yes, much & None & Yes \\
\hline Company I & Yes, much & None & Yes \\
\hline Company J & Yes, much & None & Yes, much \\
\hline Company $\mathrm{K}$ & Yes, much & Yes, mostly sales staff & None \\
\hline Company L & Some & Yes, much & Yes \\
\hline
\end{tabular}

The process begins in June, where division and regional staff members discuss key planning issues with contacts from publicrelations and advertising agencies. By August, these meetings establish key challenges for the coming year. In September and October, the corporate office sends its instructions to the property managers, who develop their marketing budgets based on those guidelines. By the end of November, the marketing plans are sent back to regional offices for approval. All plans reside in the regional offices.

A typical hotel marketing-plan document consists of a market-area overview and detailed plans for each targeted market segment, food and beverage outlet, distribution channel, communications media, and market-research activity. All plans include specific objectives, strategies, and action steps, which are stated in qualitative and quantitative terms.

New development. Company $\mathrm{K}$ is a large, international chain that operates primarily mid-scale franchised properties, plus a few company-owned locations. The company's marketing-planning process is a fairly recent development. Four years ago, only 20 percent of its hotels developed marketing plans. At the time of my study, at least 80 percent were developing marketing plans.

Company K's marketingplanning process begins in June with corporate meetings, where managers discuss each property's revenues, occupancy, average daily rate, and total revenues for the coming year. They also review each hotel's current budget, possible forecasts for the next year, and action steps. In July, the properties begin developing their marketing plan, incorporating goals, strategies, and budgets. Executive committees from the regional and property levels meet to review the 


\begin{tabular}{|c|c|c|}
\hline Time line & Training & $\begin{array}{l}\text { Incentive Plan } \\
\text { (Level, if applicable) }\end{array}$ \\
\hline 15 months,ongoing & Yes, strong emphasis & Yes \\
\hline Four months: April-July & Yes, strong emphasis & $\begin{array}{c}\text { Yes, tied to profit and guest } \\
\text { satisfaction }\end{array}$ \\
\hline Two months: June-August & $\begin{array}{l}\text { Little emphasis: } \\
\text { Guidelines only }\end{array}$ & Yes \\
\hline Yearly, ongoing & $\begin{array}{l}\text { Little emphasis: } \\
\text { Guidelines only }\end{array}$ & Yes, tied to sales quotas \\
\hline $\begin{array}{l}\text { Trimesters: Dec-May, } \\
\text { May-Sept, Sept-Dec }\end{array}$ & $\begin{array}{l}\text { Little training on general } \\
\text { principles }\end{array}$ & $\begin{array}{c}\text { Yes } \\
\text { (corporate and regional) }\end{array}$ \\
\hline Two months & Little training, special basis & Yes (property) \\
\hline Ongoing, year-round & Little emphasis & $\begin{array}{l}\text { Yes, tied to profit at the } \\
\text { property level }\end{array}$ \\
\hline Four months: April-August & None & None \\
\hline Four months: Sept-Dec & None & $\begin{array}{c}\text { Yes } \\
\begin{array}{c}\text { (corporate and property } \\
\text { level) }\end{array} \\
\end{array}$ \\
\hline Four months: June-Sept & None & $\begin{array}{c}\text { Yes, tied to profit and guest } \\
\text { satisfaction }\end{array}$ \\
\hline Two months: July-August & Yes & None \\
\hline Four months: April-July & None & $\begin{array}{l}\text { Yes, tied to profit and } \\
\text { market share }\end{array}$ \\
\hline
\end{tabular}

expected revenues from each market segment. The hotel's marketing plan is due on September 15, when the budget-approval process begins. It concludes in midOctober. All marketing plans must be approved at the regional level before they are sent to corporate executives.

The marketing plan comprises an executive summary, competitive analysis, property evaluation, and area guest inventory. This inventory is completed for each market segment in food and beverage outlets, guest rooms, meeting rooms, and all public areas. The director of sales sets projected rates and room-nights for each market segment. Department heads develop action plans and budgets for each revenue-producing area. The budget proposals are made final by the general manager and controller. After the marketing plan is approved, sales objectives are reviewed every month through a profit-and-loss report, where actual figures are compared with the marketing plan's budget.

Discussions. Company $\mathrm{L}$ is a small company that owns and operates first-class hotels mostly in the United States. It is now expanding to other countries. The marketing-planning process at the property level begins in April and ends in July. The corporate office offers little direction during this time, but there is a lot of discussion back and forth between the regional offices and the properties. Once the planning process is complete, the marketing plan goes to the regional office for approval before being sent to corporate headquarters.

Company L's marketing plan is a detailed document. It contains specific guidelines and instructions for the hotel for consistent development of the marketing plan.

\section{Thorough Planning}

The most important features in the development of a thorough marketing plan appear to be management participation and commitment at all levels, sufficient time for development, specific training in developing a marketing plan, and tying incentives to the achievement of goals and objectives. I rank Company A's and B's planning processes above the rest because they were the most thorough in terms of those four characteristics. In both cases, all levels of management were involved in the marketing-planning process, and the effort was supplemented by advertising, public-relations, and marketresearch agencies. At 15 months' duration, Company A had the lengthiest planning cycle, but the company's officials describe the planning process as ongoing. Hotel managers are always looking for market opportunities and threats that may affect the realization of their marketing plan's objectives.

Although its planning cycle was only four months, which is typical of the rest of the industry, Company B's procedure still stood out from the rest of the pack. Like Company A, it emphasized training for marketing planning at all levels in the organization. In contrast, the 
In spolte of the competitive mature of the hotel industry; setting realistic goals in the markeling plan is more of a rarity than a nom. other chains I examined made up for their lack of training with detailed instructions and guidelines for developing the marketing plan. These guidelines included specific timetables, forms, tables, and step-by-step instructions on how to go through the planning process. Unfortunately, in their effort to make the process simple to understand, most hotel companies have made the process more complex. As a result, a voluminous marketing plan is produced.

KISS. Detailed instructions not only add complexity, but they hinder the creative aspects and insight needed to assess each individual property's unique situation. Managers at each hotel should assess their own situation and develop a marketing plan based on their unique needs. By providing a structured format, hotel managers may begin to view the planning process as a routine activity, not a creative one.

The marketing plan must be kept simple and flexible to respond to changes in the environment (e.g., economic and competitive changes). Thus, the marketing plan must be re-assessed and reevaluated all the time. My study found just three hotel companies that had ongoing planning processes.

Many managers evidently approach the marketing-planning exercise with the goal of producing a final document. Such an approach renders the plan irrelevant as the environment changes. As one respondent commented: "What you get out of the process is very much a function of what you put in."

\section{Planning Benchmarks}

To reiterate, the four guidelines of a thorough marketing program are the following:

(1) An ongoing planning process that includes constant evaluation and re-assessment of the environment. This practice assists in making better forecasts.

(2) Full participation and involvement of all levels of management in the planning process. This procedure ensures complete understanding of the company's goals and the direction needed for effective execution of the marketing plan.

(3) Strong training in marketing planring. Training ensures a meaningful process that is understood by all concerned.

(4) An incentive plan that ties critical factors other than revenue and profit into the manager's bonus. Specifically, guest-satisfaction programs should be included, but most companies had not worked out a formula for this assessment. Just two hotel companies in my study exhibited a strong emphasis on guest service in their marketing-planning practices. Companies $B$ and $J$ each operate a unique incentive program that ties into their guest-satisfaction effort. General managers receive an annual bonus if they meet both their profit and guest-satisfaction goals. These two elements of the program are not independent of each other, and both must be met for the GM to be eligible for the bonus.

\section{Dimensions of Planning}

Although the hotel companies follow similar formats in their planning processes, my analysis shows that their approaches are actually quite varied. Looking at the first of the six dimensions I used to characterize the hotel company's planning process, conservative versus ambitious, I found a relationship between the size of the company and the approach to setting objectives in the planning process. Most of the large companies (A, B, $\mathrm{H}$, and $\mathrm{J}$ ) 
described their goals as ambitious, while the small companies $(C, D$, $\mathrm{G}$, and $\mathrm{L}$ ) described their objectives as realistic or optimistic.

Small companies differed from large companies on two other dimensions. First, the smaller companies had greater autonomy and less corporate direction in the planning process. This was evident in companies $\mathrm{C}, \mathrm{D}, \mathrm{F}$, and $\mathrm{L}$, which described a bottom-up approach for their planning process. In contrast, corporate-level management had more control in the larger companies. Most of the large companies (A, B, E, I, J, and K) used a topdown approach in the planning process. Management at the property level was more involved with the plan's implementation in these companies.

Second, larger companies generally used a sequential planning process, while smaller companies had the luxury of an iterative approach that moved the plan back and forth between levels for more work. This finding makes sense, considering the amount of time it would take for the marketing plan to go back and forth between levels in large companies. A sequential process is almost essential.

Examination of the other three dimensions turned up few differences among the companies. Most firms held a short-term orientation in their marketing-planning cycle, typically one year. The reason for this finding is probably that the dynamic nature of the hotel industry makes it difficult for managers to plan far into the future. Most companies use a rational approach to planning, rather than an incremental procedure. Once again, this finding probably results from the nature of the hotel environment. Managers are so busy making sure they are getting enough business to meet their budgets that they have little time to review their marketing plans on a regular basis. Finally, there was no pattern at all regarding whether the company's process was simple or complex.

Cross-pollination. Both Company $\mathrm{A}$ and Company $\mathrm{B}$ described their marketing-planning process with the same characteristics: ambitious, complex, long-term, topdown, rational, and sequential. This congruence may be purely coincidental, but both companies have so many similarities in their planning processes that mere coincidence is unlikely. One possible explanation for the similarities might be the extensive movement of management personnel among all hotel companies. Many marketing managers have worked for more than one hotel company, making a cross-pollination of companies' systems quite likely.

\section{Aggressive Objectives}

In spite of the competitive nature of the hotel industry, setting realistic goals in the marketing plan is more of a rarity than the norm. Of the 12 hotel companies I studied, just three described their objective-setting as realistic. The majority described their objectives as aggressive and ambitious. In justifying this approach, several respondents stated that they wished for their organizations to reach beyond their potential. They assumed that setting ambitious objectives would stretch their people to do better than they hoped.

Such ambitious goal setting often resulted in a tug-of-war between the corporate office and the individual properties. While the corporate office came to the table with ambitious objectives, property managers would deliberately lowball their objectives. Eventually, the two would reach a compromise agreement on a target. This game violates one of the fundamental principles of good marketing planning-namely, setting realistic goals in the first place.

\section{Refocus on the Guest}

In my discussion with hotel marketing executives, I observed that the industry's marketingplanning process has evolved into one that involves meeting objectives for sales and profit levels, and not the needs of the guest. In the push to meet sales goals, hotel managers can lose sight of the guest. In a service business like the hotel industry, one would expect that guest-service programs would be strongly emphasized, but this is not the case. I recommend that more companies adopt incentive systems similar to those offered by Companies $\mathrm{B}$ and $\mathrm{J}$ that reward managers for meeting guestsatisfaction targets along with financial goals. By integrating guest services into the marketing planning process, hotel companies will be able to focus even more strongly on their core business, which is to satisfy and serve guests. It seems likely that a marketing-plan document stated in terms of guest satisfaction would be even more useful than the current financially based plans.

The primary objective of a hotel should not be profit or revenue maximization. The objective should simply be guest satisfaction. Profit and revenue matters are constraints to be met, like debt service. Once you have satisfied your guests, the rest will automatically fall into place.

To survive in the competitive arena of the ' 90 s, hotel companies will need to refocus on guest satisfaction. They need to realize that guest satisfaction is no longer just good business practice; it is a matter of survival. All management activities, including planning, will thus have to begin and end with the guest. $\square$ 